\title{
AK Parti ve CHP'nin 2018 Seçim Beyannamelerinde Özgürlük Sorunsalının Kavramsallaştırılması Üzerine Mukayeseli Bir Değerlendirme
}

\author{
DOI: $10.26466 /$ opus. 842381
}

*

\author{
Ahmet Kizilkaya * \\ * Dr., T C. Millî Eğitim Bakanlığı, Ankara/Türkiye \\ E-Posta: ahmetkizilkaya111@gmail.com \\ ORCID: $\underline{0000-0002-7275-3664}$ \\ Öz
}

Siyasal iktidarın barışçıl bir biçimde el değiştirdiği 1950 seçimleriyle başlayan süreç, Batı demokrasilerine özgü aktör, kavram ve mekanizmaların içselleştirilmesine olanak săglayarak Türkiye'nin demokrasi kültürünün gelişmesine ciddi bir katkı sunmuştur. Çok sayıda yerel seçim, genel seçim ve referandum tecrübesine dayal olarak gelişen bu süreç, modern demokrasinin özünü ve siyasal katılımın ana imkânın oluşturan muhtelif siyasal partilerin rekabetine sahne olmuştur. 24 Haziran 2018 tarihinde gerçekleştirilen genel seçimler, hem Cumhurbaşkanlığı Hükümet Sisteminin uygulamaya geçmesine imkân tanıyan niteliği dolayısıyla hem de ittifaklar aracılığıyla seçime girilmesine olanak sağlayan düzenlemenin ilk örneğini oluşturması nedeniyle, Türkiye'nin demokrasi tarihi bağlamında önemli bir dönüm noktasın teşkil etmiştir. Bu çalışmada, 3 Kasım 2002 seçimlerinden beri ülkenin yönetimini tek başına elinde bulunduran ve Cumhur İttifakı'nın en büyük bileşenini oluşturan AK Parti ile 3 Kasım 2002 seçimlerinden bu yana ana muhalefet rolünü üstlenen ve Millet İttifakı'nın en büyük bileşenini temsil eden CHP'nin 24 Haziran 2018 seçim beyannamelerinin özgürlük sorunsal bağlamında incelenmesi amaçlanmıştır. Inceleme kapsamında, her iki siyasal partinin seçim beyannamesi, demokrasi, vatandaşlık, Kürt sorunu, sivil toplum, basın özgürlüğ̈̈ ve inanç özgürlüğ̈̈ gibi temalar üzerinden mukayese edilmiştir.

Anahtar Kelimeler: AK Parti, CHP, özgürlük sorunsal, seçim beyannamesi, 24 Haziran seçimleri. 


\title{
A Comparative Evaluation on the Conceptualization of Problematique of Freedom in 2018 Election Manifestoes of the AK Party and CHP
}

\begin{abstract}
The process that started with the peacefully government change in the 1950 elections, has contributed to development of Turkey's democracy culture by enabling Turkey to interiorize the actors, concepts and mechanisms which are specific to Western democracy. This process, which improved based on the experience of many local elections, general elections and referendums, witnessed the competition of various political parties, which constitute the essence of modern democracy and the basic means of political participation. General elections held on June 24, 2018 has constituted an important turning point in the historical context of Turkey's democracy due to both their nature that enables the Presidential Government System to be put into practice and setting the first precedent of the regulation that enables election through alliances. In this study, it is aimed to examine the June 2018 election manifestoes of both the AK Party, which has been the sole ruler of the country since the 3 November 2002 elections and constitutes the largest component of the People's Alliance, and the CHP, which has held the main opposition role since the 3 November 2002 elections and represents the largest component of the Nation Alliance, in the context of the problematique of freedom. Within the scope of the analysis, the election manifestoes of both political parties were compared on themes such as democracy, citizenship, the Kurdish issue, civil society, liberty of press and freedom of belief.
\end{abstract}

Keywords: The AK Party, The CHP, problematique of freedom, election manifesto, 25 June elections. 


\section{Giriş}

Özgürlük kavramı, tek ve kuşatıcı bir tanımın içine yerleştirilemeyecek kadar geniş ve zengin bir anlamlar örgüsünü ihtiva etmekle birlikte, onu hem insan varlı̆̆ının özünü oluşturan soyut bir kategori hem de o varlığa verili potansiyelin dış dünyada kendisini gerçekleştirebilmesinin somut koşullarını sunan bir eyleyebilme imkânı olarak tarif etmek mümkündür. Sözlük anlamına bakıldığında, özgürlük kavramının, en genel biçimiyle, kişinin kendi kendisini belirlemesi, denetlemesi, yönlendirmesi ve kendi iradesi ile gücüne dayanarak karar vermesi şeklinde tanımlandığı görülmektedir (Cevizci, 1999, s. 667). İnsanın doğal varoluşuna yapışık bir nitelik olarak özgürlük salt bir potansiyele istinat ederken, söz konusu potansiyeli dışsallaştıran etkenlerin, tek tek kişilerin bireysel yönelimlerinden ait olunan toplumsal ve kültürel çevrenin kabullerine, içinde bulunulan zaman ve mekânın koşullarından tabi olunan siyasal otoritenin karakterine dek uzanan geniş bir zeminde/zemin aracılığıyla şekillendiği söylenebilir.

Özgürlüğü, insana özgü soyut bir potansiyel olmaktan çıkararak dış dünyanın gerçekliği içinde kullanılan somut bir düşünce ve eylem biçimine dönüştüren ve ona toplumsallık ve dolayısıyla siyasallık kazandıran bütün bu etkenler, kadim insanlık tarihinin akışı içinde daralıp genişleyerek günümüze kadar ulaşan bireysel ve kolektif mücadelelerin neticesinde şekillenmiş ve hem hukuk disiplininin özünü hem de modern devlet aygıtının temel formasyonunu oluşturmuştur. Hukuk disiplini, insanların doğuştan sahip olduğu ya da sonradan elde ettiği hak ve özgürlüklerin toplumsal, kamusal ve siyasal düzeyde karşılık bulabilmesinin ilke ve kurallarını tesis ederken; devlet aygıtı, bu hak ve özgürlüklerin 'tanınmasına', 'kullanılmasına', 'sınırlandırılmasına' (Akın, 1974, s.277) dönük bir işlevselliğe sahip olmuştur ve olmaya da devam etmektedir.

Günümüzde ülkeleri ve toplumları hak ve özgürlükleri tanımlama, kullanma ve sınırlandırma kriterlerine dayalı olarak kabaca üçe ayırmamız mümkündür: Siyasal, hukuksal ve toplumsal varlığını, hak ve özgürlüklerin mümkün olan en geniş şekilde tecessüm etmesi için biçimlendirmişbiçimlendiren ülkeler; bunları söylem düzeyinde kabul eden ancak çoğunlukla uygulamaya dönüştürmeyen/yansitmayan ülkeler ve kendisini hiçbir şekilde bu hususlarla kayıtlı görmeyen ülkeler. Esasında bu sınıflandırmayı siyaset bilimi literatüründeki tanımıyla uyumlu olarak gelişmiş demokrasi- 
ler, az gelişmiş demokrasiler ve anti-demokratik rejimler şeklinde ifade etmek de mümkündür. Bu açıdan bakıldığında, evrensel düzeyde kabul görmüş hak ve özgürlüklerin bir ülkede kendisine bulduğu ya da bul(a)madığ1 karşılıklar, söz konusu ülkenin demokratikleşme indeksinin ne düzeyde olduğunu ortaya koyan ölçütler olarak karşımıza çıkmaktadır. Hak ve özgürlük kavramları ile demokrasi kavramı arasındaki bu yakın ve doğru orantılı ilişkiselliğin sağlıklı şekilde formüle edildiği ülkelerde, insanların gerek doğuştan getirdiği gerekse sonradan edindiği etnik, kültürel, dinsel, siyasal ve toplumsal özellikler bir çatışma aracı ya da kaynağı olmaktan çıkarılmış; bireysel ve toplumsal nitelikli her türlü farklılık bir arada ve uyum içinde yaşamanın imkânı olarak görülmüştür. Zira insanlığın modernizme koşut bir şekilde işleyen ve tebaadan vatandaşlı̆̆a doğru evrilen siyasal ve toplumsal mücadeleler tarihi, ulusların maddi-manevi gelişmesinin ve kalıcı bir barış ortamına kavuşmasının yolunun temel hak ve özgürlüklerin tüm toplumu kuşatacak denli kapsayıcı olmasından geçtiğini gösteren örneklerle doludur. Bugün dünyanın en gelişmiş demokrasileri olarak kabul edilen ve hatta demokrasinin beşiği olarak gösterilen Amerika Birleşik Devletleri'nin $(A B D)$ ve Avrupa Birliği'nin $(A B)$ nasıl kurulduğunu ve hangi referansları esas alarak geliştiğini hatırlamak yeterlidir. Uzunca bir süre devam eden ve köleliğin kaldırılmasıyla sonuçlanan iç savaşın ardından kısa sürede dünyanın iki süper gücünden biri haline gelen $\mathrm{ABD}$ ile küresel düzeyde etkili olan ve milyonlarca insanın ölümüyle sonuçlanan iki büyük savaşın akabinde kurulan $A B$ 'nin siyasal tarihleri, temel hak ve özgürlükler ile demokrasi arasındaki ilişkinin nasıl kurumsallaştırılması gerektiğini gösteren en yetkin örneklerdendir (Kızllkaya, 2013, s.21).

Türkiye de, özellikle çok partili hayata geçtiği 1945 yılından itibaren hak ve özgürlükler ile demokrasi arasındaki ilişkinin görece gelişmiş modellerini ortaya koyan bu örnekleri biçimsel düzeyde de olsa kendisi için temel hedef olarak belirlemiş; Köker' in (2005, s. 219) ifadesiyle "potansiyel olarak liberal-demokratik bir rejime dönüşmeye açık, Batıcı bir zihniyet" ekseninde yol almaya başlamıştır. Çok partili demokratik siyasal yaşam, her ne kadar sık aralıklarla gerçekleşen askeri darbe ve muhtıralar dolayısıyla kesintiye uğramış ve vesayetçi paradigmaların gölgesi altında kalmış olsa da, Türkiye'nin demokrasi kültürünün gelişmesine ciddi bir katkı sunmuştur. Yaklaşık yetmiş yıldır devam eden bu süreçte Türkiye, geç Osmanlı döneminden bu yana aşina olduğu Batı demokrasilerine özgü aktör, kavram ve meka- 
nizmaları derinlikli bir şekilde içselleştirmiştir. Modern demokrasinin özünü ve siyasal katılımın imkânını oluşturan muhtelif siyasal partilerin rekabeti, genel ve eşit oy ilkesine dayalı olarak gerçekleştirilen serbest seçimlerin varlığı ve seçmenlere dönük propaganda sürecini içeren siyasal iletişim olanaklarının etkin bir biçimde kullanılması gibi unsurları bu bağlamda zikretmek mümkündür.

Siyasal iktidarın barışçıl bir biçimde el değiştirdiği 1950 seçimleriyle başlayan süreç, söz konusu unsurların katılımını esas alan bir çizgi içinde ve birçok yerel seçim, genel seçim ve referandum tecrübesini kapsayacak şekilde günümüze kadar devam etmiştir. Türk siyasal tarihinin genel seçimler bağlamındaki en son tecrübesi ise 24 Haziran 2018 tarihinde yaşanmıştır. Bu tarihte yapılan genel seçimler, aynı zamanda Türkiye' nin Cumhurbaşkanlığı Hükümet Sistemi olarak adlandırılan yeni yönetim modeline göre gerçekleştirilen ilk seçim tecrübesi olarak da kayıtlara geçmiştir. Cumhurbaşkanl1ğı seçimi ile eş zamanlı olarak gerçekleşen 24 Haziran 2018 Genel Seçimleri, önceki seçim tecrübelerinden farklı olarak, siyasal partilerin tek başına katılımının yanı sıra, seçim öncesinde bir araya gelerek oluşturdukları ittifaklar aracılığıyla katılımına da imkân sağlamıştır. Bu seçimlerin bir ucunda Adalet ve Kalkınma Partisi (AK Parti), Milliyetçi Hareket Partisi (MHP) ve Büyük Birlik Partisi'nin (BBP) yer aldığı Cumhur İttifakı, diğer ucunda ise Cumhuriyet Halk Partisi (CHP), İYI Parti, Saadet Partisi (SP) ve Demokrat Parti'nin (DP) bulunduğu Millet İttifakı oluşmuştur.

Bu çalışmada, Cumhur İttifakı'nın en büyük bileşenini oluşturan ve 3 Kasım 2002 seçimlerinden beri ülkenin yönetimini tek başına elinde bulunduran AK Parti ile Millet İttifakı'nın en büyük bileşenini temsil eden ve 3 Kasım 2002 seçimlerinden bu yana ana muhalefet rolünü üstlenen CHP'nin 24 Haziran 2018 seçim beyannamelerinin, özgürlük sorunsalına denk gelen demokrasi, vatandaşlık, Kürt sorunu, sivil toplum, basın özgürlüğü ve inanç özgürlüğü gibi temalar üzerinden incelenmesi amaçlanmaktadır. İnceleme kapsamında, öncelikle siyasal parti, seçim, siyasal iletişim ve seçim beyannamesi gibi temel kavramlar tanımlanacaktır. Bunu takip eden bölümlerde ise, her iki partinin seçim beyannameleri genel özellikleri itibarıyla analiz edilecek ve özgürlük sorunsalını nasıl algıladıkları-formüle ettikleri mukayeseli olarak ve etraflıca tartışlacaktır. 


\section{Temel Kavramlar ve Tanımlar}

Toplumsal alandaki bölünme ve çatışmaları yansıtan ve temsil eden aktörler olarak siyasal partileri, kendilerini belirli bir ideolojik kimlik içinde tanımlayan ve yasal/meşru zeminde örgütlenerek toplumsal destek sağlamaya ve devlet aygitının kontrolünü ele geçirmeye çalışan tüzel kişilikler şeklinde tarif etmek mümkündür (Özbudun, 1975, s.1; Sarıbay, 1997, s.10). Siyasal partiler, aynı zamanda vatandaşların yönetsel süreçlere dâhil olmasını sağlayan ve "modern devleti geleneksel devletten ayıran en önemli öğe olan" (Özer, 1988, s.156) siyasal katılımı gerçekleştirmenin birincil aracı olarak da işlev görmektedir.

Siyasal partilerin dışında, demokratik bir sistemin zorunlu koşulu olan bir başka önemli unsur da seçim olgusudur. Seçmenlerin, siyasal partiler aracılığıyla irade ve tercihlerini ortaya koymasını sağlayan mekanizma olan seçim olgusunu, en genel ifadesiyle, yönetenlerin yönetilenler tarafından belirlendiği ve yetkilendirildiği bir işlem olarak tarif etmek mümkündür (Türk, 2006, s.76). Demokratik bir sistemde, ülkenin belirli bir süre zarfınca hangi parti/partiler tarafından yönetileceği (iktidar) ve hangi parti/partiler tarafından denetleneceği (muhalefet) hususu, yalnızca genel ve eşit oy ilkesine dayalı olarak gerçekleştirilen serbest seçimler aracılığıyla belirlenir (Türk, 2006, s.77).

Bu seçimlerin adil ve özgür bir rekabet ortamında gerçekleştirilebilmesi hususu ise siyasal iletişim/siyasal pazarlama kavramları ile tariflenen alana işaret etmektedir. Siyasal iletişim kavramı, siyasal aktörlerin ideolojik amaç ve projeksiyonlarını muhtelif grup, ülke ya da bloklardan oluşan hedef kitleye kabul ettirmek ve gerektiğinde eyleme dönüştürmek üzere kullandığı çeşitli iletişim tür ve tekniklerini içermektedir (Aziz, 2007, s. 4). Toplumsal iknanın sağlanması ve toplumsal rızanın üretilmesini amaçlayan bu iletişim süreci, dönemsel koşul ve önceliklere bağlı olarak tercih edilen reklam, propaganda ve halkla ilişkiler çalışmalarını ihtiva eden tek yönlü ya da çift yönlü bir çabayı yansıtmaktadır (Uslu, 1996, 790).

Seçim beyannameleri, sözlü iletişim tekniklerinin yanı sıra, yazılı iletişim ve kitle iletişimi şeklinde farklılaşabilen bu yöndeki çabaların en önemli araçlarından biridir. Bu beyannameler, "siyasal partilerin muhtemel iktidarları döneminde yaşama geçirmeyi vaat ettikleri uygulamaları, ülkenin sorunlarına yaklaşımlarını ve bunlara yönelik çözüm önerilerini içeren" (Beriş, 
2011, s. 109) ve seçim süreçlerinde kullanılan bağlayıcı metinlerdir. Siyasal partilerin hangi politika alanlarına öncelik verdiğini, bu önceliklerin değişik partiler arasında nasıl farklılaştığını, tüm partilerin vurguladığı ortak önceliklerin olup olmadığını ve belirlenen öncelikler ile ülkenin genel gündemi arasında bir paralellik bulunup bulunmadığını gösteren bu metinler, ilgili siyasal partilerin analiz edilebilmesi açısından önemli bir kaynak niteliğini taşımaktadır (Aytaç, 2017, s. 8-9). Dolayısıyla siyasal iletişim sürecinin merkezi kavramlarından biri olan seçim beyannameleri, yalnızca kampanya dönemleriyle sınırl bir zaman dilimini incelemeye değil, aynı zamanda siyasal partilerin genel gidişat içindeki konumunu da süreklilik ve değişim ilişkisi içinde irdelemeye/karşılaştırmaya imkân sunmaktadır.

\section{Genel-Tematik Özellikleri Bağlamında AK Parti ve CHP'nin 2018 Seçim Beyannameleri}

AK Parti ve CHP'nin 2018 seçimleri öncesinde yayımladıkları seçim beyannameleri, iktidar ve ana muhalefet partilerinin kendilerini nasıl tanımladıklarını, mevcut durumu nasıl ve hangi öncelikler üzerinden analiz ettiklerini ve gelecek projeksiyonlarını hangi temalar ekseninde ve ne türden parametrelere dayalı olarak şekillendirdiklerini göstermesi bakımından önem taşımaktadır. Bu beyannameleri, ele alınan temaların çeşitliliğinden tercih edilen söylemsel araçlara, slogan seçiminden konuların tasnif edilme biçimlerine kadar uzanan geniş bir farklılıklar dizini olarak değerlendirmek de mümkündür. Söz konusu beyannameler, bu yönüyle, adı geçen partilerin seçmenlerle kurduğu/kuracağı ilişkinin özgün karakterini ortaya koyduğu gibi, ideolojik yönelimlerini ve entelektüel birikimini de yansıtmaktadır. Bunları karşılaştırmalı bir bakış açısı içinde irdeleyebilmek için, her iki partinin seçim beyannamelerinin içerdiği genel-tematik özelliklerin/tercihlerin ana hatlarıyla ele alınmasında yarar bulunmaktadır.

'Güçlü Meclis, Güçlü Hükümet, Güçlü Türkiye' ve 'Yaparsa Yine AK Parti Yapar' sloganlariyla yayımlanan AK Parti'nin 2018 seçim beyannamesi, Cumhurbaşkanı Recep Tayyip Erdoğan'ın sunuşunu takiben yer verilen geleceğe ilişkin vizyon açılamasıyla başlamaktadır. Söz konusu vizyon metni, sonraki bölümlerde ortaya konulan ve yedi ana tema ekseninde detaylandırılan başlıkların küçük bir özeti niteliğini taşımakta olup, 'Türkiye'nin her alanda hızlı bir kalkınma sürecine gireceği' vurgusunu öne ç1- 
karmakta ve 'milli değerlerini evrensel değerlerle buluşturan, güçlü ve büyük Türkiye'nin hep birlikte inşa edileceği' sözü ile sonlandırılmaktadır.

Vizyon metninin hemen ardından gelen ilk bölüm 'yeni yönetim modeli' başlığını taşımaktadır. Bu bölümde, 24 Haziran seçimlerinin yeni yönetim sistemini hayata geçireceği belirtilmekte ve yeni sistem kapsamında yasama, yürütme ve yargı erklerinin nasıl şekilleneceği izah edilmektedir. Yasama ve yürütme erklerinin temel niteliği 'güçlülük' vurgusu ile, yarg1 erkinin temel niteliği ise 'bağımsızlık ve tarafsızlık' vurgusu ile öne çıkarılmaktadir.

AK Parti beyannamesinin ikinci bölümü 'güçlü demokrasi' üst başlığıyla, haklar ve özgürlüklere, din-devlet-ilişkisine, katılımcllık ve sivil topluma, şeffaflık ilkesine, adalete ve güven içinde yaşama hakkına değinmektedir. 'İnsan ve toplum' üst başlığını taşıyan üçüncü bölümde, nitelikli eğitim ve öğretimden kültür ve sanata, gençlik ve kadın konusundan çalışma hayatına, yoksullukla mücadeleden istihdama ve göç olgusuna kadar uzanan geniş bir alanı içerecek şekilde muhtelif toplumsal konulara yönelik açıklamalar yapılmaktadır.

Beyannamenin dördüncü başlığı 'istikrarlı ve güçlü ekonomi' adını taşımakta ve istihdam, ticaret, yatırım, özelleştirme, girişimcilik, turizm ve benzeri mali ve ekonomik konuları içermektedir. Beşinci başlıkta, bilim ve teknoloji, gida ve tarım, dijitalleşme, enerji ve madencilik ile savunma, havacilık ve uzay sanayii alanlarını kapsayan 'stratejik sektörler ve yenilikçi üretim' konusu işlenmektedir. Altıncı bölüm, 'çevre, şehircilik ve yerel yönetimler' üst başlığı altında tasnif edilen küresel ısınma, kentsel dönüşüm, doğal kaynakların yönetimi ve bölgesel kalkınma gibi temaları ihtiva etmektedir. Yedinci ve son bölümde ise mülteciler, yurtdışında yaşayan Türk vatandaşları, küresel adalet/ayrımcllık ve terörle mücadele gibi hususlar 'dış politika ve milli güvenlik' üst başlığı altında ele alınmaktadır. Seçim beyannamesinin içerdiği bütün bu başlıklar altında, öncelikle 3 Kasım 2002 seçimlerinden bu yana süregelen AK Parti iktidarları döneminde yapılan icraatlar anlatılmakta, ardından da bundan sonraki dönemde ulaşılmak istenen hedefler izah edilmektedir. Söz konusu beyanname, halen devam eden ve ileride yapılacağı belirtilen büyük altyapı ve yatırım projelerinin anlatıldığ 1 ek bir bölüm ile son bulmaktadır.

'Millet için geliyoruz' sloganıla yayımlanan CHP'nin 2018 seçim beyannamesi/bildirgesi ise, partinin kurumsal kimliğinin dayanaklarını oluş- 
turduğu belirtilen ilkeleri izah eden manifesto niteliğinde bir metin ile başlamaktadır. Hamasi tonu ve retorik düzeyi oldukça yüksek olan bu metinde, CHP'nin Türkiye'nin kurtuluşuna ve Cumhuriyetin kuruluşuna damgasını vurmuş bir parti olduğu belirtilmekte, insan haklarına ve çoğulcu demokrasiye dayalı bir bakış açısı içinde yirmi birinci yüzyılın da öncü partisi konumunda bulunduğu ifade edilmektedir.

Bu manifestonun ardından, beyannamenin on bir üst başlık altında tasnif edilen bölümlerine geçilmektedir. Mevcut duruma ilişkin analizlerin yapıldığı ve geleceğe dönük hedeflerin açıklandığı bu bölümlerin ilk beşinin diğer bölümlere nazaran daha öncelikli bir şekilde konumlandırıldığı göze çarpmaktadır. 'Demokrasi: hak, hukuk, adalet' üst başlı̆̆ını taşıyan birinci bölümde, Türkiye'nin demokratik uygar dünyadan uzaklaştığı ve bir tek adam rejimine dönüştüğü iddia edilmekte, bunun önüne geçmek için yapılması hedeflenen düzenlemelere değinilmektedir.

İkinci bölümde, 'ekonomi: üreten, büyüyen, hakça bölüşen Türkiye' üst başlı̆̆1 altında, ülke ekonomisinin karşı karıya bulunduğu belirtilen olumsuzluklara atıfta bulunulmakta ve bu olumsuzlukları aşmak için geliştirilen kısa, orta ve uzun vadeli hedefler açıklanmaktadır. 'Eğitim: iş garantili, parasız, nitelikli eğitim' üst başlı̆̆ıyla oluşturulan üçüncü bölümde, eğitimde eşit olanakların sağlanacağı ve yeni bir anlayışın inşa edileceği vurgulanmaktadır. Dördüncü bölümde 'toplumsal barış: kardeşlik ve birlikte yaşam' üst başlığı altında, inançlara saygıyı esas alan özgürlükçü laiklik ilkesinin yaşama geçirileceği ve Kürt sorununun çözüleceği belirtilmektedir. ‘Dış politika: istikrar ve itibar' üst başlığını içeren beşinci bölümde, ülkenin kurum ve teamüllerini hiçe sayan bir tek adam diplomasisi yaratıldığ 1 ileri sürülmekte ve dış politikaya ilişkin hedefler ifade edilmektedir. CHP'nin seçim bildirgesinde yer alan diğer altı başlık altında ise, sırasıyla 'kamu yönetimi ve hizmetleri', 'adil ve insan onuruna yaraşır bir çalışma hayatı', 'toplum kesimleri', 'kültür ve sanat', 'kent hakkı' ve 'doğa dostu bir yaşam' üst başlıklarına değinilmekte ve muhtelif konulara ilişkin perspektif ve hedefler izah edilmektedir. 


\section{AK Parti ve CHP'nin Seçim Beyannamelerinde Özgürlük Sorunsalı: Mukayeseli Bir İnceleme}

24 Haziran seçimleri, 16 Nisan 2017 referandumu ile kabul edilen ve Cumhurbaşkanlığı Hükümet Sistemi olarak adlandırılan yeni yönetim modelinin hayata geçirileceği ilk seçim olması hasebiyle, sistem tartş̧malarının gölgesinde gerçekleşmiştir. Bu seçimlerde gerek iktidar partisinin gerekse ana muhalefet partisinin referandum sürecinden bu yana savunageldiği tezler seçim beyannameleri bağlamında bir kez daha yinelenmiş ve partilerin siyasal tutum alı̧larındaki temel parametrelerden biri olmuştur. AK Parti, yeni yönetim modeli sayesinde Türkiye'nin yapısal sorunlarını çözeceğini ve daha rasyonel bir biçimde yönetileceğini iddia ederken; $\mathrm{CHP}$, güçlendirilmiş parlamenter sistemin savunuculuğunu üstlenmiştir.

Bu süreç, beyannameler bağlamında öne çıkan ve her iki siyasal partinin de kendi pozisyonlarını ifade etmek üzere başvurduğu 'özgürlük' argümanı ile bu argüman uyarınca geliştirilmiş savlar üzerinden temellendirilmiştir. AK Parti'nin seçim beyannamesinde, yeni yönetim modeli kapsamında yapılacak reformların milli iradeyi güçlendireceği, demokratik siyaset alanını genişleteceği ve vesayetçi yapıları ortadan kaldıracağı vurgulanmıştır. CHP'nin seçim beyannamesinde ise, her ne kadar yeni yönetim modeli isim olarak zikredilmiş olmasa da, Türkiye'nin 'kişiselleşmiş' ve 'keyfileşmiş' bir tek adam rejiminin tehdidi altında olduğu, Türkiye Büyük Millet Meclisi'nin (TBMM) egemenlik haklarının elinden alındığı, kuvvetler ayrılığı ilkesinin yok sayıldığı ve sorunların ancak güçlendirilmiş parlamenter demokrasinin yeniden tesis edilmesiyle çözülebileceği ileri sürülmüştür.

Her iki siyasal partinin, "Türk tipi başkanlık sistemi” olarak da tanımlanan yeni yönetim modeline dönük bu genel perspektifleri, özgürlük sorunsalını hangi kavram ya da kavramlar ekseninde algılayıp formüle ettiklerini göstermesi bakımından önem taşımaktadır. AK Parti, 'milli irade' ve 'demokrasi' kavramları eşliğinde yeni yönetim modelinin özgürlükçü doğasına atıfta bulunurken; CHP, aynı modeli 'tek adam rejimi' ve 'demokrasi krizi'ne yol açmakla suçlamaktadır.

İlgili partilerin bu tutumlarını, 2018 seçimleri için yayımladıkları beyannamelerin özgürlük sorunsalına denk gelen ve demokrasi üst başlığı altında yer verilen muhtelif temalar kapsamında içerdiği açıklamaların detaylarında da görmek mümkündür. AK Parti beyannamesinin demokrasi üst başlığ1 
altında içerdiği temalar, temel ilkelere atıfta bulunan beş ayrı kategoriyi ihtiva etmektedir. Buna karşılık, CHP'nin demokrasi üst başlığı altında yer verdiği temalar, ilkelerin yanı sıra, tanım ve hedefleri de kapsayan ve alt maddeleri de içeren on ayrı kategoride tasnif edilmektedir.

Her iki beyannamenin de, 'demokrasi' konulu bölümleri mevcut duruma ilişin genel bir değerlendirme ile başlamaktadır. Söz konusu değerlendirme kapsamında, AK Parti'nin seçim beyannamesinde, uzun yıllardır devam eden iktidarları süresince yapılan reform ve çalışmaların kısa bir özeti sunulmakta ve 'milli irade' kavramının bu süreçteki yegane motivasyon kaynağını oluşturduğu ifade edilmektedir. Milli iradenin beklenti ve ihtiyaçları doğrultusunda demokratik hukuk devletini tahkim etme ve vatandaşların hak ve özgürlüklerini genişletme gayesinin, AK Parti'nin bugüne kadarki tüm seçim beyannamelerine ve hükümet programlarına yans1yan en önemli hedefleri arasında yer aldığı belirtilmekte; güçlü demokrasinin, ekonomik gelişme ve insani kalkınmanın da temelini oluşturduğu bilinciyle, demokratik standartların daha da yükseltileceği vaat edilmektedir.

CHP'nin seçim beyannamesinde yer alan 'demokrasi' üst konulu genel değerlendirme ise, 'hak', 'hukuk' ve 'adalet' vurgularını öne çıaran bir perspektif içinde geliştirilen ve AK Parti'nin 3 Kasım 2002 seçimlerinden beri süregelen iktidarları dönemindeki politika ve uygulamaları eleştiren tezlere dayanmaktadır. Gücü tek elde toplamaya çalışmakla ve siyasal çoğulculuk ile serbest seçim mekanizmalarını ortadan kaldırmakla itham edilen ve 'saray rejimi' olarak tanımlanan AK Parti iktidarının, özgürlükleri ve hukuku kendi varlığına karşı bir tehdit olarak algıladığı, bu nedenle de demokrasi için en büyük tehlike kaynağı haline geldiği iddia edilmektedir.

CHP'nin seçim beyannamesinde, 'tek adam rejimi', 'otoriter tek adam rejimi', ‘saray rejimi' ya da 'baskıcı ve tekçi iktidar' gibi tanımlamalara sıklıkla başvurulduğu gözlenmektedir. Bu tanımlamaların tamamı, Türk demokrasisini kurumsuz ve kuralsız bıraktığı ileri sürülen AK Parti iktidarının yol açtı̆̆ belirtilen 'otoriter yönetim anlayışını' betimlemek üzere kullanılmaktadır. Bu tanımlamalar eşliğinde tasvir edilen 'anti-demokratik gerçekliğin' önüne geçmek içinse 'özgür yurttaşlar cumhuriyeti' şeklinde isimlendirilen bir vaatler/hedefler listesi sunulmaktadır. Bu liste kapsamında, askıya alınan ya da ihlal edilen anayasal ve evrensel hakların yeniden ihya edileceği, ifade ve eleştiri özgürlüğünün sınırlarının genişletileceği ve özgürlükçü demokrasinin önündeki tüm engellerin kaldırılacağı belirtilmektedir. 
CHP'nin seçim beyannamesinde yer verilen ve kendisini hedef alan bu ağır iddia ve ithamlara karşın, AK Parti, hukukun üstünlüğü ilkesi çerçevesinde bireysel hak ve özgürlükleri evrensel bir miras ve anayasal düzenin temel ahlaki referansı olarak kabul ettiğini, geride bıraktığı 16 yıllık iktidarları döneminde de bu kabule uygun bir perspektif ile hareket ettiğini anlatan çok sayıda örnekten bahsetmektedir. Söz konusu örnekler aracilığıyla, anti-demokratik ve yasakçı düzenlemelerin sonlandırılmasından insan hakları alanında gerçekleştirilen reformlara, sivil toplumun alanının genişletilmesinden muhtelif toplumsal grupların hak ve özgürlük sorunlarının giderilmesine dek uzanan geniş bir icraat listesi sunulmakta ve demokratikleşme sürecinin bundan sonraki dönemlerde de aynı hız ve kararlılıkla sürdürüleceği ifade edilmektedir.

Görülebileceği üzere, her iki siyasal parti de, demokrasi üst başlığı altında hak ve özgürlükler kavramma merkezi bir yer ve önem atfetmektedir. AK Parti'nin beyannamesi, iktidar partisi olmanın doğal bir sonucu olarak, geçmişteki olumlu uygulamaların aktarımını ve geleceğe dönük hedefleri içerirken; CHP'nin beyannamesi, ana muhalefet partisi olmanın doğal bir sonucu olarak, geçmiş ve mevcut uygulamaların eleştirisi ile ileriye dönük vaatleri kapsamaktadır. Tabii beyannamelerin geçmiş ve mevcut duruma yönelik olarak içerdiği analizleri ve ileriye dönük vaatleri, yalnızca iktidarda ya da muhalefette olmanın getirdiği doğal bir refleks ve ayrım olarak nitelendirmek de doğru değildir. Zira bu hususlar aynı zamanda iktidar ve ana muhalefet partisinin özgürlük sorunsalını nasıl algıladıklarını gösteren genel ideolojik perspektiflerini ve gelecek vizyonlarını da ortaya koymaktadır.

2018 seçim beyannamelerinin özgürlük sorunsalına denk gelen bazı parametreler eşliğinde mukayese edilmesi konunun anlaşılması bakımından elzemdir. Bu noktada, özellikle vatandaşlık kavramının nasıl tanımlandığı, Kürt sorununun ne ölçüde ve hangi kapsamda zikredildiği, sivil toplum olgusunun hangi bağlamlarda ele alındığı, basının/basın özgürlüğünün ne şekilde konumlandırıldığ 1 ve inanç özgürlüğünün nasıl temellendirildiği gibi sorular önem kazanmaktadır.

AK Parti ve CHP'nin seçim beyannameleri incelendiğinde, vatandaşlık kavramının birbirine yakın bir içerikle ve neredeyse benzer sözcüklerle tanımlandığı gözlenmektedir. Her iki siyasal parti de 'eşit vatandaşlık' vurgusunun altını çizmekte; inancı, kimliği, kökeni ya da bireysel farklılıkları dolayısıyla kimsenin dışlanmadığı evrensel nitelikli bir vatandaşlık tanımını 
benimsediğini ifade etmektedir. Ancak aralarındaki bu benzerliklere rağmen, AK Parti'nin vatandaşlık tanımında 'kapsayıcı vatandaşlık' vurgusu öne çıkarılmakta, CHP'nin tanımında ise 'özgürlükç̧ü vatandaşlık' anlayışına öncelik verilmektedir.

AK Parti ve CHP'nin vatandaşlık tanımları arasındaki bu nüans, Türkiye'nin önemli ve öncelikli konularından ve değişmeyen gündem maddelerinden biri olan Kürt sorununa dönük yaklaşımlarının da özünü oluşturmaktadır. AK Parti'nin seçim beyannamesinde 'Kürt sorunu' şeklinde bir ifade ya da tanım kullanılmamış olmakla birlikte, geride bırakılan 16 yıllık iktidar dönemi içinde Kürt vatandaşlarının her türlü insani meselesinin demokrasi ve refah sorunu olarak görüldüğü; ret, inkâr ve asimilasyon politikalarına son verildiği belirtilmektedir. Buna mukabil, CHP'nin seçim beyannamesinde, Kürt sorunu, münhasıran kendisi için ayrılmış özel bir başlik altında incelenmektedir. Cumhuriyet tarihinin en önemli sorunlarının başında geldiği belirtilen Kürt sorununun, CHP'nin olası bir iktidarında özgürlük, demokrasi ve hukuk devleti ilkelerinden hareketle kalıcı ve nihai bir biçimde çözüleceği ifade edilmektedir.

2018 seçim beyannamelerinin sivil toplum merkezli yaklaşımları da, özgürlük sorunsalının anlaşılmasına dönük önemli parametrelerden birini oluşturmaktadır. AK Parti beyannamesinde, ileri demokrasilerin standartlarına kavuşmak için vatandaşın katılımını esas alan güçlü bir sivil toplumun varlığına yönelik ihtiyacın altı çizilmekte; bugüne kadar yapıldığı gibi, bundan sonra da sivil toplumun geliştirilmesine dönük faaliyetlere devam edileceği belirtilmektedir. Muhtelif hukuksal düzenlemeleri, kurumsal yenilikleri, mali yardımları ve benzeri hususları içeren bu faaliyetler aracılığıyla, çağdaş dünya ile bütünleşmiş güçlü bir sivil toplumun inşasının hedeflendiği açıklanmaktadır. CHP beyannamesinde ise, özgürlükçü demokrasinin ve denge denetleme mekanizmalarının vazgeçilmez bir unsuru olarak tanımlanan sivil toplumun gelişmesinin önündeki engellerin kaldırılacağı, siyasal baskı ve müdahalelerden kurtarılacağı, kurumsal ve mali özerkliklerinin sağlanacağı vurgulanmaktadır. Yaklaşımlarındaki bu farklılıklara karşın, her iki parti de, sivil toplum olgusunu katılıma bir demokrasinin gereği olarak gördügünü belirtmekte ve seçim beyannamesinin önemli bir başlığ olarak konumlandırmaktadır.

Demokrasinin vazgeçilmez öğelerinden bir başkası olan basının/basın özgürlüğünün ise her iki partinin seçim beyannameleri kapsamında asimet- 
rik bir şekilde konumlandırıldığı gözlenmektedir. AK Parti'nin seçim beyannamesinde basın/basın özgürlüğü kavramı yalnızca bir kez geçerken, CHP'nin seçim beyannamesinde münhasıran bu kavram için tahsis edilmiş uzun sayılabilecek bir bölüm bulunmaktadır. İktidar partisinin beyannamesinde yalnızca basın özgürlügünün genişletildiği yönündeki vurguyla iktifa edilirken; ana muhalefet partisinin beyannamesinde, basının dördüncü kuvvet olarak tanımlanmasından internet ve sosyal medya yasaklarının kaldırılmasına, tutuklu gazetecilerin serbest birakılmasından devlet sirrı kavramının kapsamının daraltılmasına kadar uzanan detaylı bir analiz yapilmaktadir.

AK Parti ve CHP'nin 2018 seçim beyannamelerinde karşlık bulan önemli bir konu başlığı da inanç özgürlüğüdür. Her iki parti de konuyu laiklik ilkesi temelinde ele almakta ve özgürlükçü bir bakış açısıyla yorumlamaktadır. Geçmiş dönemin inanç özgürlügünü kısıtlayan baskıcı ve yasakçı laiklik uygulamalarına son verildiğini belirten AK Parti'nin beyannamesinde, tüm inanç kesimlerinin hiçbir ayrımcllı̆̆a maruz kalmaksızın özgür bir şekilde inançlarının ve kimliklerinin gereğini yaşayabilmelerinin önemine dikkat çekilmekte ve her inanç grubuna eşit mesafede duran bir laiklik anlayışının benimsendiği vurgulanmaktadır. Laiklik ilkesinin inanç ve ibadet özgürlüğünün en temel teminatı olduğunu belirten CHP beyannamesinde de benzer vurgular yer almakta; din, mezhep ve inanç farkı gözetmeksizin her vatandaşın inanç ve ibadet özgürlüğünün güvence altına alınacağına işaret edilmektedir.

\section{Sonuç}

Türkiye'nin çok partili demokratik siyasal yaşama geçtiği 1945 yılından günümüze dek yapılan genel seçimler arasında 24 Haziran seçimlerinin istisnai bir yeri bulunmaktadır. Bu seçimler, gerek Cumhurbaşkanlığı Hükümet Sistemi olarak adlandırılan yeni yönetim modelinin hayata geçirilmesini sağlayan niteliği dolayısıyla gerekse siyasal partilerin tek başına katılımının yanı sıra, seçim öncesinde bir araya gelerek oluşturdukları ittifaklar aracılığıyla seçime girebilmesine imkân sunması nedeniyle ülkenin demokrasi tarihi bağlamında önemli bir dönüm noktasını teşkil etmiştir.

İktidar partisinin en büyük bileşenini temsil ettiği Cumhur İttifakı ile liderliğini ana muhalefet partisinin üstlendiği Millet İttifakı arasındaki siyasal 
rekabetin ilk deneyimini oluşturan 24 Haziran seçimlerinin kampanya süreci, yeni yönetim modeline dönük tartısmalar etrafında şekillenmiştir. AK Parti ve CHP'nin bu süreçte hazırlamış olduğu seçim beyannameleri de söz konusu tartısmaların etkisi altında formüle edilmiştir. AK Parti, yeni yönetim modeli sayesinde Türkiye'nin adeta bir şahlanış dönemine gireceğini ve demokratik gelişmesi ile ekonomik kalkınmasını hızlandıracağını ileri sürerken; $\mathrm{CHP}$, iktidarın geçmiş ve mevcut politika ve uygulamalarına dönük eleştiriler üzerinden ülkenin baskıcı ve otoriter bir tek adam rejimine doğru sürüklendiğini iddia etmiştir.

Her iki siyasal partinin demokrasi, vatandaşlık, Kürt sorunu, sivil toplum, basin özgürlüğü ve inanç özgürlüğü gibi muhtelif temalar ekseninde kendisini gösteren özgürlük sorunsalına ilişkin perspektifleri de, seçim beyannamelerini karakterize eden bu genel yaklaşımları içinde şekillenmiştir. AK Parti, 3 Kasım 2002 seçimlerinden itibaren süregelen iktidarları süresince gerçekleştirdiği icraatlara atıfta bulunan bir yöntemle gelecek dönemde de milli iradeyi esas alan, insani ve ekonomik kalkınmayı öne çıaran 'güçlü bir demokrasinin' inşasını hedeflediğini açılamıştır. CHP ise, neredeyse tüm demokratik hak ve özgürlükleri ortadan kaldırmakla itham ettiği AK Parti'nin yönetim anlayışını tasfiye edeceğini ve onun yerine, 'hak', 'hukuk' ve 'adalet' kavramları ile özgür vatandaşlara ve özgürlükçü demokrasiye dayanan bir cumhuriyet inşa edeceğini vaat etmiştir.

Ancak temeldeki bu karşıtlıklarına rağmen, her iki partinin seçim beyannamesinde ortak vurgular eşliğinde tanımlanan kavramlar/ilkeler de yer almıştır. Gerekçeleri ve hedefleri farklı olmakla birlikte, her iki parti de vatandaşlık, sivil topum ve inanç özgürlügü kavramlarını/ilkelerini benzer şekilde formüle etmiştir. AK Parti ve CHP'nin 2018 seçim beyannameleri, bireysel ve grup aidiyetlerinden kaynaklanan farklılıkların bir ayrımcılık ya da ötekileştirme gerekçesi olamayacağını belirten eşit vatandaşlık ilkesinin yanı sıra, sivil toplumun güçlendirilmesini ve inançlara saygılı özgürlükçü bir laiklik anlayışını savunan yönleriyle benzeşmiştir.

Buna karşlık, aynı beyannameler, Kürt sorunu ve basın özgürlüğü temalarını ele alan yanlarıyla da birbirlerinden belirgin ölçüde farklılaşmıştır. AK Parti'nin seçim beyannamesinde Kürt sorunu ifadesine hiç yer verilmemiş, bunun yerine sadece bir defaya mahsus olmak üzere Kürt vatandaşları ibaresi kullanılmıştır. Bu ibare de, Kürt sorunu temelinde yaşanan insani meselelerin AK Parti'nin geride bıraktığı iktidar dönemleri içinde yaptı̆̆ reform- 
lar sonucunda zayıfladığını ifade eden geçmiş zaman kipi içinde ele alınmış ve beyannamede bu soruna özgülenen bir gelecek vaadine yer verilmemiştir. Oysa aynı sorun CHP'nin seçim beyannamesinde özel bir başlık altında ve geleceğe dönük çözüm perspektifi/önerisi eşliğinde analiz edilmiştir. Benzer şekilde, AK Parti'nin seçim beyannamesinde sadece bir kez kullanılan basın özgürlüğü kavramı, CHP'nin seçim beyannamesinde uzunca bir bölümün konusu olarak ele alınmış ve ileriye dönük vaatler çerçevesinde tartışılmıştır. 


\section{EXTENDED ABSTRACT}

\section{A Comparative Evaluation on the Conceptualization of Problematique of Freedom in 2018 Election Manifestoes of the AK Party and CHP}

Ahmet Kizllkaya

Ministry of National Education

Nowadays, it is possible to roughly split countries and societies into three based on the criteria for defining, using and limiting rights and freedoms; i) countries that are shaping or have shaped their political, legal and social existence in order to embody rights and freedoms in the broadest possible way, ii) countries that adopt these at a discourse level but mostly do not put in to practice or reflect, and iii) countries that are indifferent to these issues. In fact, it is possible to express this classification as developed democracies, developing democracies and non-democratic regimes in accordance with the political science literature. From this point of view, the fact that universally accepted rights and freedoms make or cannot make a perfect sense in a country appears as criteria revealing the level of the democratization index of the mentioned country. In countries where this close and directly proportional relationality between the concepts of right and freedom and the concept of democracy is formulated properly, people's ethnic, cultural, religious, political and social characteristics, both innate and acquired, are no longer a tool or source of conflicts; all kinds of individual and social differences were seen as an opportunity to live together in harmony. The history of the political and social struggles of humanity that has run in parallel with modernism and has evolved from the vassal to citizenship is full of examples showing that the way for nations to develop materially and morally and to attain a perpetual peace environment is that fundamental rights and freedoms are so inclusive that they encompass the entire society. It is sufficient to remember how the United States of America (USA) and the European Union (EU) which are considered as the most developed democracies of the world today and even shown as the cradle of democracy were founded and which references they use for developing based on. Political histories of both the USA, which became one of the two superpowers of the world in a short time after the civil war that continued for a long time and resulted in the abolition of slavery, 
and the EU, which was established after two great wars that had a global impact and resulted in the deaths of millions of people, are the most competent examples showing how the relationship between fundamental rights and freedoms and democracy should be institutionalized (Kizllkaya, 2013, p. 21).

Turkey has also set these examples, which reveals relatively developed models of the relationship between rights and freedoms and democracy, as the main objective for itself even so a formality level since 1945 when the multiparty system is transitioned to; and has started to proceed on the axis of "a Western mentality, potentially open to transforming into a liberal-democratic regime" as expressed by Köker (2005, p. 219). Multi-party democratic political life has presented a serious contribution to the development of Turkey's democratic culture, although it has interrupted because of the military coup and memorandum that took place at frequent intervals and has been in the shadow of guardianship paradigms. In this nearly seventy years long-standing process, Turkey has deeply interiorized the actors, concepts and mechanisms which are specific to Western democracy that was acquainted with since the late Ottoman period. It is possible to mention the elements such as the competition of various political parties that constitutes both the essence of modern democracy and the basic means of political participation, the existence of free elections held on the basis of general and equal-vote principle and the effective use of political communication opportunities including the propaganda process towards the voters in this context.

The process that started with the peacefully government change in the 1950 elections, has continued until today in a line based on the participation of these aforementioned elements and covering many local elections, general elections and referendum experiences. The last experience of Turkish political history in the context of general elections was on June 24, 2018. This general election held on the date has also passed into the history as the first election experience held on according to the Turkey's new management model named as the Presidential Government System. Unlike previous election experiences, the June 24, 2018 General Elections, which held on simultaneously with the presidential election, enabled political parties to participate alone, as well as through the alliances they made before the elections. On one side of these elections there was the People's Alliance which includes Justice and Development Party (AK Party), Nationalist Movement Party (MHP) and Great Union Party (BBP), on the other 
side the Nation Alliance including Republican People's Party (CHP), İYI Party, Felicity Party (SP) and Democrat Party (DP).

In this study, it is aimed to examine the June 2018 election manifestoes of both the AK Party, which has been the sole ruler of the country since the 3 November 2002 elections and constitutes the largest component of the People's Alliance, and the $\mathrm{CHP}$, which has held the main opposition role since the 3 November 2002 elections and represents the largest component of the Nation Alliance, in the context of the problematique of freedom corresponding to themes such as democracy, citizenship, Kurdish issue, civil society, liberty of the press and freedom of belief. Within the scope of the analysis, firstly basic concepts such as political party, election, political communication and election manifesto will be defined. In the following parts, the election manifestoes of both parties will be analyzed in terms of their general characteristics, and how they perceive and formulate the problematique of freedom will be discussed comparatively and in detail.

\section{Kaynakça / References}

Adalet ve Kalkınma Partisi (2018). AK Parti 2018 Cumhurbaşkanlı̆̆ı Seçimleri ve Genel Seçimler Seçim beyannamesi. 08.12 .2020 tarihinde https://www.akparti.org.tr/media/271931/secim-beyannamesi-2018.pdf adresinden erişildi.

Akın, İ. F. (1974), Kamu hukuku. İstanbul: İstanbul Üniversitesi Yayınları.

Aytaç, S.E. (2017). Türkiye'de siyasi partilerin seçim beyannamelerindeki politika öncelikleri: 2002-2015. Siyasal: Journal of Political Sciences, 26(2), 7-26.

Aziz, A. (2007). Siyasal İletişim. Ankara: Nobel Yayınları.

Beriş, H.E. (2011). AK Parti 2007-2011 seçim beyannameleri: Süreklilik ve değişim. (H. Turşucu ve H.E. Beriş, Der.). Lider Ülke Türkiye: 10. Dönem Ders Notlar içinde (s.109-141) .Ankara: AK Parti Ar-Ge Başkanlığı Yayınları,

Cevizci, A. (1999). Felsefe sözlüğü. İstanbul: Paradigma Yayınları

Cumhuriyet Halk Partisi (2018). CHP 2018 seçim bildirgesi. 08.12.2020 tarihinde http://secim2018.chp.org.tr/files/CHP-SecimBildirgesi-2018-icerik.pdf?v=3 adresinden erişildi.

Kızılkaya, A. (2013). Özgürlük bilinci içinde ilerlemenin öyküsü. Stratejik Düşünce Dergisi, 49, 21-24.

Köker, L. (2005). Modernleşme, Kemalizm ve demokrasi. İstanbul: İletişim Yayınları. 
Özbudun, E. (1975). Türkiye'de sosyal değişme ve siyasal katılma. Ankara: Ankara Üniversitesi Hukuk Fakültesi Yayınları.

Özer, İ. (1988). Toplumsallaşma sürecinin siyasal boyutu, siyasal katılma ve kentlileşme. Hacettepe Üniversitesi İktisadi ve İdari Bilimler Fakültesi Dergisi, 6 (1-2), 153-169.

Sarıbay, A.Y. (1997). 99 soruda siyasal partiler. İstanbul: Radikal Gazetesi Yayınları.

Türk, H.S. (2006). Seçim, seçim sistemleri ve anayasal tercih. Anayasa Yargısı Dergisi, 23, 75-113.

Uslu, Z.K. (1996). Siyasal iletişim ve 24 aralık 1995 genel seçimleri. Yeni Türkiye Dergisi, 11, 790-802.

\section{Kaynakça Bilgisi / Citation Information}

Kızılkaya, A. (2021). AK Parti ve CHP'nin 2018 seçim beyannamelerinde özgürlük sorunsalının kavramsallaştırılması üzerine mukayeseli bir değerlendirme. OPUS-Uluslararası Toplum Araştırmaları Dergisi, 17(33), 654-673. DOI: 10.26466/opus.842381 